\title{
Effect of Nucleotides on Broiler Performance and Carcass Yield
}

\section{author(s)}

Pelícia VC

Sartori JR

Zavarize $\mathrm{KC}$

Pezzato AC

Stradiotti $A C$

Araujo PC

Mituo MAO

Madeira LA

Universidade Estadual Paulista (Unesp), Faculdade de Medicina Veterinária e Zootecnia, Campus de Botucatu.

\section{ABSTRACT}

This study aimed at evaluating the effect of nucleotides on the performance and carcass yield of broilers fed diets with no antibiotic growth promoters (AGP), anticoccidials, or animal feedstuffs. In the trial, 600 Ross 308 male broilers were distributed in a completely randomized experimental design into six treatments with four replicates of 25 birds each. Treatments consisted of a control diet (CD), CD + AGP, CD + $0.04 \%, C D+0.05 \%, C D+0.06 \%$, and CD + 0.07\% nucleotides. The experimental diets did not contain anticoccidials, and birds were vaccinated against coccidiosis at three days of age. No significant differences were detected among broilers submitted to the different treatments in none of the studied parameters. Under the conditions of this experiment, diets supplemented with nucleotides did not influence broiler performance or carcass yield at 42 days of age, and were not different from the feeds not containing any additive or with AGP.

\section{INTRODUCTION}

Antibiotic growth promoters (AGP) in animal diets have been banned in several countries due to the public concern with the emergence of antibiotic-resistant bacteria, which may pose human health risks. This has made meat-exporting countries, such as Brazil, to follow this trend. Moreover, Brazilian consumers are increasingly aware of product quality, and today require healthy foods with no chemical residues.

In order to supply this new market, some poultry companies produce the so-called "alternative chickens", which are broilers reared with diets with no inclusion of AGPs, anticoccidials, and animal feedstuffs (Demattê Filho \& Mendes, 2001).

Birds fed AGP-free diets are more susceptible to infections caused by pathogens that cause enteric diseases, which may compromise nutrient absorption, and consequently, live performance.

In order to prevent performance losses in poultry production, several natural alternatives to AGPs have been studied. Nucleotides may be one of these alternatives. The beneficial effect of nucleotides on intestinal cell integrity, development, and turnover, with significant proliferation of crypt cell was already demonstrated (Tsujinaka et al., 1993; Dell'Orto et al., 2002). Nucleotides also increase intestinal villi length, and improve the immune response of broilers, promoting nutrient absorption and increased weight gain (Yu et al., 2002). They have also significant effects on enterocytes during intestinal development, maturation, and repair after damage caused by stress or pathogens (McCauley et al., 1998).

The addition of yeast extract to broiler diets improves weight gain and feed conversion ratio (Rutz et al., 2006). The authors suggested that this performance improvement is a consequence of increase in villi height due to the action of nucleotides present in yeast extract. This 
improves nutrient digestion and absorption capacity because the absortive surface area is increased.

There are few studies in literature using nucleotides as additives in broiler diets. Therefore, the objective of the present study was to evaluate the effect of nucleotide supplementation on the performance and carcass yield of broilers.

\section{MATERIAL AND METHODS}

The experiment was carried out at FMVZ-UNESP, in an experimental broiler house divided into 24 pens measuring $2.5 \mathrm{~m}^{2}$. In this trial, 600 male Ross 308 broilers were distributed in a completely randomized experimental design with six treatments with four replicates of 25 birds each, totaling 100 birds per treatment. Treatments consisted of: control diet (CD), $C D+10$ ppm AGP (Surmax 100 ${ }^{\circledR}$ - Elanco), $C D+$ $0.04 \%$ nucleotides, $C D+0.05 \%$ nucleotides, $C D+$ $0.06 \%$ nucleotides, and $C D+0.07 \%$ nucleotides (AccelerAid $^{\circledR}$ - FormilVet). No anticoccidials were added to the diets. Birds were vaccinated against coccidiosis (Paracox $5^{\circledR}$-Schering Plough Coopers) at three days of age. Feed and water were supplied ad libitum during the entire experimental period.

The rearing period was divided in four phases: prestarter (1-7 days), starter (8-21 days), grower (22-35 days), and finisher (36-42 days). Feeds were based on corn and soybean meal, and were formulated to contain equal protein and energy levels in all treatments. Bird nutritional requirements were established for each rearing phase according to the tables of Rostagno et al. (2005).

Performance data were collected and analyzed for the accumulated periods of 1 to 7,1 to 21 , and 1 to 42 days of age. The parameters body weight, weight gain, feed conversion ratio, mortality, and production factor were analyzed for these periods. At 42 days of age, data on carcass and parts yield were also collected and analyzed. Five birds per pen, totaling 20 birds per treatment, were randomly collected, fasted for eight hours, electrically stunned, and bled. After evisceration and chilling in a cold storage (the chiller was not used), carcasses were weighed and cut up. All slaughter, evisceration and cut-up procedures followed industry standards. Carcass yield (with feet, head, neck, and fat pad) was calculated relative to live weight. Breast, leg (drum+thigh), and wing yields were calculated relative to eviscerated carcass weight.

Performance and carcass yield data were submitted to analysis of variance at a level of $5 \%$ significance, using the GLM procedure of the software program SPSS 13.0 for Windows.

\begin{tabular}{|c|c|c|c|c|}
\hline Ingredients & Pre-starter & Starter & Grower & Finisher \\
\hline Corn & 55.843 & 59.025 & 61.844 & 65.920 \\
\hline Soybean meal & 37.492 & 34.520 & 30.928 & 27.077 \\
\hline Soybean oil & 2.160 & 2.375 & 3.343 & 3.318 \\
\hline $\mathrm{NaCl}$ & 0.520 & 0.500 & 0.480 & 0.450 \\
\hline Vitamin Suppl. ${ }^{1}$ & 0.100 & 0.100 & 0.100 & 0.100 \\
\hline Mineral Suppl. ${ }^{2}$ & 0.050 & 0.050 & 0.050 & 0.050 \\
\hline Calcitic limestone & 0.910 & 0.880 & 0.830 & 0.785 \\
\hline Dicalcium phosphate & 1.950 & 1.800 & 1.670 & 1.520 \\
\hline DL-methionine & 0.240 & 0.175 & 0.175 & 0.165 \\
\hline L-lysine & 0.375 & 0.215 & 0.230 & 0.275 \\
\hline Choline chloride $^{3}$ & 0.060 & 0.060 & 0.050 & 0.040 \\
\hline AccelerAid ${ }^{\circledR 4}$ & \multicolumn{4}{|c|}{$0.150(C D+0.04 \%), 0.200(C D+0.05 \%)$} \\
\hline \multicolumn{5}{|c|}{$0.250(C D+0.06 \%), 0.300(C D+0.07 \%)$} \\
\hline Growth promoter ${ }^{5}$ & \multirow{2}{*}{\multicolumn{4}{|c|}{$\begin{array}{l}0.001(C D+A G P) \text { except for the finisher phase } \\
\text { Between } 0.050 \text { and } 0.292 \text { as inert material }\end{array}$}} \\
\hline Kaolin 6 & & & & \\
\hline \multicolumn{5}{|l|}{ Calculated values } \\
\hline ME (kcal/kg) & 2950 & 3000 & 3100 & 3150 \\
\hline$C P(\%) \quad 22.0$ & 20.8 & 19.4 & 18.0 & \\
\hline Calcium (\%) & 0.94 & 0.88 & 0.83 & 0.76 \\
\hline Available phosphorus & s $(\%) 0.47$ & 0.44 & 0.41 & 0.38 \\
\hline Dig. methionine (\%) & 0.54 & 0.47 & 0.45 & 0.43 \\
\hline Dig. Met + Cys (\%) & 0.84 & 0.75 & 0.72 & 0.68 \\
\hline Dig. lysine (\%) & 1.37 & 1.17 & 1.10 & 1.05 \\
\hline Potassium (\%) & 0.84 & 0.80 & 0.74 & 0.68 \\
\hline Sodium (\%) & 0.23 & 0.22 & 0.21 & 0.20 \\
\hline Chlorine (\%) & 0.36 & 0.34 & 0.33 & 0.31 \\
\hline Linoleic acid (\%) & 2.44 & 2.59 & 3.14 & 3.18 \\
\hline
\end{tabular}

1 Vitamin supplement Vaccinar Nutrição e Saúde Animal (per $\mathrm{kg}$ feed): vit. A, 15,000 IU; vit. D3, 3,000 IU; vit. E, 30 mg; vit. K3, 4 mg; B1, 3 mg; vit. B2, 6 mg; vit. B6, 6 mg; vit. B12, 30 mcg; niacin, 40 mg; folic acid, $1.5 \mathrm{mg}$; pantothenic acid, $15 \mathrm{mg}$; biotin, $120 \mathrm{mcg}$; vit. C, 50 mg; antioxidant. 2 Mineral supplement Vaccinar Nutrição e Saúde Animal (per $\mathrm{kg}$ feed): selenium, $180 \mathrm{mcg}$; iodine, $700 \mathrm{mcg}$; iron, 48 $\mathrm{mg}$; copper, $10 \mathrm{mg}$; manganese, $78 \mathrm{mg}$; zinc, $55 \mathrm{mg}$. 3 choline chloride $(70 \%) .4$ AccelerAid $^{\circledR}$ - FormilVet containing $22.5 \%$ total nucleotides. 5 Surmax $100^{\circledR}$ Elanco. 6Vehicle used to replace nucleotides and antibiotic growth promoter in the diets.

\section{RESULTS AND DISCUSSION}

There was no effect of treatment on the performance parameters analyzed at 7,21 , and 42 days of age (Table 2). Zavarize et al. (2007) also did not observe any performance improvement in broilers fed a diet supplemented with $0.05 \%$ nucleotides as compared to those fed a non-supplemented diet. On the other hand, Bruno (2009) evaluated the effect of different nucleotides levels (0 to $0.05 \%$ ) on broiler performance, and observed a linear improvement during the period of 1 to 21 days of age; however, the same benefit of nucleotides was not observed during the subsequent periods. Rutz et al. (2006) verified broiler performance improvement when broilers were fed yeast extracts, and attributed the better performance 


\begin{tabular}{|c|c|c|c|c|c|c|c|}
\hline \multirow[t]{2}{*}{ Parameter } & \multicolumn{7}{|c|}{ Nucleotide inclusion level } \\
\hline & $C D$ & $C D+0.04 \%$ & $C D+0.05 \%$ & $C D+0.06 \%$ & $C D+0.07 \%$ & $C D+A G P$ & C.V. (\%) \\
\hline \multicolumn{8}{|c|}{1 to 7 days of age } \\
\hline IW, g & 45.6 & 45.5 & 45.4 & 45.6 & 45.8 & 45.6 & 0.6 \\
\hline BW, g & 172 & 173 & 180 & 170 & 178 & 175 & 4.2 \\
\hline WG, g & 126 & 128 & 135 & 125 & 133 & 129 & 5.7 \\
\hline $\mathrm{Fl}, \mathrm{g}$ & 146 & 151 & 151 & 150 & 151 & 151 & 4.5 \\
\hline FCR & 1.16 & 1.18 & 1.12 & 1.20 & 1.15 & 1.17 & 4.7 \\
\hline $\mathrm{MO}, \%^{1}$ & 1.06 & 1.06 & 0.71 & 0.71 & 0.71 & 0.71 & 50.8 \\
\hline \multicolumn{8}{|c|}{1 to 21 days of age } \\
\hline BW, g & 844 & 838 & 869 & 877 & 895 & 868 & 5.0 \\
\hline WG, g & 799 & 793 & 824 & 831 & 850 & 823 & 5.4 \\
\hline $\mathrm{Fl}, \mathrm{g}$ & 1.154 & 1.166 & 1.193 & 1.170 & 1.225 & 1.176 & 4.4 \\
\hline FCR & 1.45 & 1.48 & 1.45 & 1.41 & 1.44 & 1.44 & 2.2 \\
\hline $\mathrm{MO}, \%^{1}$ & 1.77 & 1.81 & 0.71 & 1.06 & 0.71 & 1.77 & 56.4 \\
\hline \multicolumn{8}{|c|}{1 to 42 days of age } \\
\hline BW, $g$ & 2.810 & 2.766 & 2.846 & 2.819 & 2.871 & 2.865 & 4.5 \\
\hline$W G, g$ & 2.764 & 2.720 & 2.801 & 2.774 & 2.825 & 2.820 & 4.6 \\
\hline $\mathrm{Fl}, \mathrm{g}$ & 4.852 & 4.860 & 4.945 & 4.897 & 5.017 & 4.946 & 3.5 \\
\hline FCR & 1.77 & 1.82 & 1.78 & 1.77 & 1.79 & 1.76 & 1.8 \\
\hline $\mathrm{MO}, \%^{1}$ & 2.67 & 2.50 & 1.41 & 1.06 & 1.06 & 1.77 & 62.7 \\
\hline $\mathrm{PF}^{2}$ & 344 & 325 & 367 & 369 & 373 & 369 & 8.3 \\
\hline
\end{tabular}

1 - Percentages were submitted to transformation $(x+0.5) 1 / 2$, before the analysis of variance. 2 - Production factor $=((D W G \times$ Livability $) / F C R) x$ 100 .

to the beneficial effect of the nucleotides present in the yeast extract.

There was no effect of nucleotides on carcass and parts yields (Table 3). Rutz et al. (2006) observed in broilers fed yeast extract (nucleotide source) a numerical improvement in carcass yield, as well as in drum, thigh, wing and breast yields as compared to birds that did not receive yeast extract. However, it must be noted that yeast extract contains other nutrients in addition to nucleotides, such as amino acids, vitamins, and minerals, which may contribute to increase carcass yield.

According to literature, dietary nucleotides may improve the immune response (Yu et al., 2002) and accelerate intestinal epithelium repair after lesions caused by pathogens (Bueno et al., 1994). This would be the expected result in broilers raised under the above-mentioned alternative production system, with consequent performance improvement.

In the present experiment, broilers were vaccinated against coccidiosis and reared on new litter and under strict health control. Therefore, these birds did not have to face the challenges typically present in the field, which may be one of the possible causes of the absence of differences among treatments.

\section{CONCLUSION}

Under the conditions of this experiment, diets supplemented with nucleotides did not influence broiler performance or carcass yield at 42 days of age, and were not different from the feeds not containing any additive or with AGP.

New studies are warranted to evaluate the effect of nucleotides added to broiler diets under the challenges typically found in commercial farms.

\begin{tabular}{|c|c|c|c|c|c|c|c|}
\hline \multirow[t]{2}{*}{ Parameter } & \multicolumn{7}{|c|}{ Nucleotide inclusion level } \\
\hline & $C D$ & $C D+0.04 \%$ & $C D+0.05 \%$ & $C D+0.06 \%$ & $C D+0.07 \%$ & $C D+A G P$ & C.V. (\%) \\
\hline Carcass $(\%)^{1}$ & 69.25 & 70.26 & 71.33 & 70.10 & 70.25 & 70.80 & 3.9 \\
\hline Head and neck $(\%)^{1}$ & 5.77 & 5.65 & 5.62 & 5.75 & 5.87 & 5.82 & 8.5 \\
\hline Feet $(\%)^{1}$ & 3.70 & 3.67 & 3.71 & 3.65 & 3.69 & 3.72 & 7.8 \\
\hline Abdominal fat $(\%)^{1}$ & 1.97 & 1.81 & 1.75 & 1.66 & 1.70 & 1.93 & 23.6 \\
\hline Wings $(\%)^{2}$ & 11.66 & 11.56 & 11.35 & 11.63 & 11.42 & 11.63 & 4.8 \\
\hline Breast $(\%)^{2}$ & 35.89 & 37.23 & 37.19 & 36.69 & 36.60 & 34.79 & 11.5 \\
\hline Legs $(\%)^{2}$ & 31.28 & 31.29 & 30.84 & 31.81 & 31.74 & 31.49 & 5.0 \\
\hline
\end{tabular}

1 - Percentage relative to live weight. 2 - Percentage relative to eviscerated carcass. 


\section{REFERENCES}

Bruno JBC. Efeito dos diferentes níveis de nucleotídeos em frangos de corte alimentados com probióticos [dissertação]. Pirassununga (SP): Universidade de São Paulo; 2009.

Bueno J, Torres M, Almendros A, Carmona R, Nunez MC, Rios A, Gil A. Effect of dietary nucleotides on small intestinal repair after diarrhea. Histological and ultrastructural changes. Gut 1994; 35:926-933.

Dell'orto V, DI Giancamillo A, Savoini G. Influence of nucleotides and glutamine dietary supplementation on gut health of weanling piglets. Journal of Animal Science 2002; 80(1):220.

Demattê Filho LC, Mendes CMI. Viabilidade técnica e econômica na criação alternativa de frangos. Anais da Conferência APINCO de Ciência e Tecnologia Avícolas; 2001; Campinas, São Paulo. Brasil. Campinas: FACTA; 2001. p.255-266.

McCauley R, Kong SE, Hall J. Glutamine and nucleotide metabolism within enterocytes. Journal Parenteral Enteral Nutrition 1998; 22:105-111.

Rostagno HS, Albino LF T, Donzele JL, Gomes PC, Oliveira RF, Lopes DC, Ferreira AS, Barreto SLT. Tabelas brasileiras para aves e suínos: composição de alimentos e exigências nutricionais. Viçosa(MG): UFV; 2005. p.186.

Rutz F, Anciuti MA, Rech JL, Gonçalves FM, Delgado AD, Rosa ER, Zauk N, Ribeiro CLG, Silva RR, Dallmann PR. Desempenho e características de carcaças de frangos de corte recebendo extrato de levedura na dieta. Ciência Animal Brasileira 2006; 7:349355.

SPSS 13.0 for Windows. Release 13.0. New York; 2004.

Tsujinaka T, lijima S, Kido Y. Role of nucleoside and nucleotide misture in intestinal mucosal growth under total parenteral nutrition. Nutrition 1993; 9:532-535.

Zavarize KC, Sartori JR, Pelícia VC, Pezzato AC, Araujo PC. Desempenho de frangos de corte criados no sistema alternativo suplementados com L-glutamina e nucleotídeos. Anais da Conferência APINCO 2007 de Ciência e Tecnologia Avícolas; 2007; Santos; São Paulo. Brasil. Campinas: FACTA; 2007. p.113113.

Yu IT, Wu JF, Yang PC, Liu CY, Lee DN, Yen HT. Roles of glutamine and nucleotides in combination in growth, immune responses and FMD antibody titles of weaned pigs. Animal Science 2002; 75:379-385. 